\title{
DUKUNGAN INTERNAL ATAU EKSTERNAL; SELF-COMPASSION DAN PERCEIVED SOCIAL SUPPORT SEBAGAI PREDIKTOR STRES
}

\author{
Maria Theresia A. F. Lim ${ }^{1}$ dan Sandi Kartasasmita ${ }^{2}$ \\ ${ }^{1}$ Fakultas Psikologi, Universitas Tarumanagara Jakarta \\ Email:theresialim92@gmail.com \\ ${ }^{2}$ Fakultas Psikologi, Universitas Tarumanagara Jakarta \\ Email: seinama2003@yahoo.com
}

\begin{abstract}
The purpose of this study is to find out which variable is more accurate at predicting stress caused by daily hassles in university students; self-compassion or perceived social support. Stress is a condition that arise when individuals perceive that there is a discrepancy between the experienced demands and the resources needed to fulfill these demands. Daily hassles are everyday demands or problems that are irritating, trigger frustration, and cause stress. Self-compassion is the attitude of treating yourself well, understanding, supporting, and full of compassion. Perceived social support is an individual perception that social support will be available when needed, and make individuals feel that other people love, care, and respect said individual. The participants for this study are 573 students aged 17 to 26 years. Measuring instruments used consist of the Perceived Stress Scale-10, Self-Compassion Scale, and Multidimensional Scale of Perceived Social Support. Data analysis was performed by multiple regression analysis technique. The result of the study shows several findings. First, the self-compassion variable is more accurate at predicting stress caused by daily hassles compared to perceived social support variable. Second, the dimension of self-compassion is the strongest predictor of stress because daily hassles are the dimension of isolation. Third, the source of perceived social support that is most able to predict stress due to daily hassles is the perceived social support from friends.
\end{abstract}

Keywords: stress, daily hassles, self-compassion, perceived social support, university students

\begin{abstract}
ABSTRAK
Tujuan dari penelitian ini adalah mengetahui variabel mana yang lebih kuat memprediksi stres yang disebabkan daily hassles pada mahasiswa; self-compassion atau perceived social support. Stres merupakan kondisi yang dihasilkan saat individu mempersepsikan bahwa terdapat diskrepansi antara tuntutan-tuntutan yang dialami dan sumber-sumber yang diperlukan untuk memenuhi tuntutan-tuntutan tersebut. Daily hassles merupakan tuntutan atau masalah seharihari yang menjengkelkan, memicu frustrasi, dan menyebabkan stres. Self-compassion merupakan sikap memperlakukan diri sendiri dengan baik, pengertian, mendukung, dan penuh kasih sayang. Perceived social support merupakan persepsi individu bahwa dukungan sosial akan diterima saat diperlukan, dan membuat individu merasa orang lain cinta, sayang, peduli, dan menghargai individu tersebut. Partisipan penelitian merupakan 573 mahasiswa berusia 17 hingga 26 tahun. Alat-alat ukur yang digunakan terdiri dari Perceived Stress Scale-10, Self-Compassion Scale, dan Multidimensional Scale of Perceived Social Support. Analisis data dilakukan dengan teknik analisa regresi ganda. Hasil penelitian menunjukkan beberapa hal. Pertama, variabel self-compassion lebih kuat memprediksi stres yang disebabkan daily hassles dibandingkan dengan variabel perceived social support. Kedua, dimensi selfcompassion yang paling kuat memprediksi stres karena daily hassles adalah dimensi isolation. Ketiga, sumber perceived social support yang paling mampu memprediksi stres karena daily hassles adalah perceived social support yang didapatkan dari teman.
\end{abstract}

Kata kunci: stres, daily hassles, self-compassion, perceived social support, mahasiswa

\section{PENDAHULUAN}

\section{Latar Belakang}

Semua orang mengalami tantangan dalam kehidupan sehari-hari. Terkadang, tantangan atau tuntutan tersebut akan terasa sangat besar dan sulit untuk diatasi. Saat inilah individu akan mengalami stres. Stres didefinisikan sebagai kondisi yang dihasilkan saat individu mempersepsikan bahwa terdapat diskrepansi antara tuntutan-tuntutan yang dialami dan sumbersumber yang diperlukan untuk memenuhi tuntutan-tuntutan tersebut (Lazarus \& Folkman, 1984; Sarafino \& Smith, 2014). Stres tidak hanya disebabkan oleh bencana atau kejadian yang besar; 
stres juga dapat disebabkan oleh kejadian-kejadian 'kecil' sehari-hari yang dialami semua orang dan disebut sebagai daily hassles (Sarafino \& Smith, 2014; Antonovsky, dalam Buch, 2006; Kanner, Coyne, Schaefer, \& Lazarus, 1981; Lazarus \& Folkman, 1984). Daily hassles adalah tuntutan atau masalah sehari-hari yang menjengkelkan, memicu frustrasi, dan menyebabkan stres. Beberapa contoh dari berbagai daily hassles adalah kehilangan barang, bertengkar dengan pasangan, bertemu orang yang menjengkelkan, memiliki tanggung jawab yang terlalu banyak, merasa kesepian, atau tidak memiliki uang yang cukup untuk membeli makanan (Kanner et al., 1981; Lazarus \& Folkman, 1984).

Mahasiswa termasuk dalam kelompok yang rentan mengalami stres, khususnya stres yang disebabkan oleh daily hassles. Berbagai penelitian yang telah dilakukan pada mahasiswa baik dalam dan luar negeri, dengan total beribu-ribu responden, telah menemukan bahwa mahasiswa seringkali mengalami stres, baik dalam tingkat rendah, rata-rata, atau tinggi (Leppink, Odlaug, Lust, Christenson, Grant, 2016; Apremahirsty \& Paramita, 2013; Pathmanathan \& Husada, 2013; American College Health Association, 2013; Fitasari, 2011; Carolin, 2010; Associated Press \& mtvU, 2009, 2008; Abdulghani, 2008).

Berbagai penelitian telah menemukan bahwa sumber stres bagi mahasiswa kebanyakan berupa daily hassles (Ainscough, Stewart, Colthorpe, \& Zimbardi, 2017; Apremahirsty \& Paramita, 2013; Purwati, 2012; Associated Press \& MtvU, 2008, 2009). Beberapa contoh daily hassles yang ditemukan sering dialami mahasiswa termasuk: (a) nilai akademik, seperti mendapat nilai buruk atau tidak sesuai harapan; (b) tugas-tugas akademik, seperti kekhawatiran saat akan melakukan presentasi oral, persiapan untuk presentasi, kesulitan dalam menyusun skripsi, menghadapi mata kuliah yang dianggap sulit atau tidak penting, adanya praktik, atau deadline tugas; (c) kehidupan perkuliahan, seperti peraturan atau kebijakan-kebijakan kampus, jadwal perkuliahan, sikap para dosen atau dosen yang tidak disukai, materi kuliah yang membingungkan, atau tidak bisa mengatur waktu; (d) kegiatan ekstrakurikuler, seperti bekerja, menjalankan program magang atau memiliki banyak kegiatan sehingga tumpang tindih dengan jadwal kuliah dan terjadi prokrastinasi; (e) masalah dengan keluarga, teman, pacar, atau hubungan interpersonal lainnya; (f) kekhawatiran finansial; (g) kekhawatiran tentang kesehatan fisik dan mental; (h) kekhawatiran tentang mendapat pekerjaan setelah lulus kuliah; (i) kekhawatiran tentang pendidikan selanjutnya; dan (j) masalah perjalanan sehari-hari, seperti jarak yang jauh antara rumah dan kampus dan kondisi jalan yang macet.

Stres dari daily hassles yang dialami dapat menyebabkan berbagai dampak negatif pada kehidupan mahasiswa (Leppink, Odlaug, Lust, Christenson, Grant, 2016; Denovan \& Macaskill, 2016; American College Health Association, 2013; Apremahirsty \& Paramita, 2013; Purwati, 2012; Melisa \& Astrini, 2012; Associated Press \& mtvU, 2008, 2009). Beberapa dampak negatif yang telah ditemukan berbagai penelitian termasuk; tidak mampu menyelesaikan tugas akademik, mengalami penurunan performa, melakukan prokrastinasi akademik, tidak ingin bersosialisasi, merasa kewalahan dengan semua hal yang harus ditangani, menjadi tidak fokus dalam mengerjakan sesuatu, mengalami depresi sehingga merasa sulit untuk menjalankan aktivitas sehari-hari, seringkali merasa panik dan emosi negatif lain yang memunculkan perilaku marahmarah dan menangis, dan menangis saat mengalami sesuatu yang dianggap tidak bisa ditangani. Beberapa dampak negatif fisiologis termasuk sering sakit kepala, mengalami perubahan nafsu makan, dan sulit tidur.

Pengalaman stres dapat berbeda-beda bagi berbagai individu. Suatu stressor, atau stimulus yang menimbulkan stres (Lazarus \& Folkman, 1984; Sarafino \& Smith, 2014), belum tentu akan menimbulkan tingkat stres yang sama pada Individu A dan juga pada Individu B. Reaksi individu terhadap suatu stressor dan tingkat stres yang dirasakan individu saat dihadapi stressor 
dipengaruhi oleh cognitive appraisal yang dilakukan individu (Lazarus \& Folkman, 1984; Sarafino \& Smith, 2014). Cognitive appraisal adalah proses di mana individu menilai seberapa besar ancaman suatu tuntutan, dan sumber daya apa saja yang dimiliki individu untuk memenuhi tuntutan tersebut.

Cognitive appraisal melibatkan proses-proses kognitif yang memengaruhi bagaimana individu menilai suatu stressor, dan akibatnya seberapa besar tingkat stres yang dirasakan individu. Salah satu proses kognitif yang dapat terlibat dalam cognitive appraisal adalah self-compassion. Selfcompassion merupakan suatu proses kognitif, di mana individu memiliki mindset atau pola berpikir positif terhadap diri sendiri, yang ditandai dengan sikap perhatian dan memahami diri, daripada sikap yang terlalu kritis atau menilai (Neff, 2003a, 2003b, 2003c). Self-compassion adalah memberikan compassion kepada diri sendiri, di mana tersentuh dan terbuka dengan kesulitan yang dialami diri sendiri, tidak menghindar atau mengabaikannya, dan menimbulkan keinginan untuk meringankan kesulitan diri dan menyembuhkan diri dengan kebaikan hati. Allen dan Leary (2010) menambahkan bahwa inti dari self-compassion adalah memberikan kepedulian, kebaikan, dan kasih sayang kepada diri sendiri seperti yang diberikan kepada orang lain yang sedang mengalami kesulitan atau masalah.

Self-compassion terdiri dari tiga komponen utama, yaitu self-kindness, recognition of common humanity, dan mindfulness, di mana ketiga komponen tersebut saling bertumpang tindih dan berhubungan (Neff, 2003a, 2003b, 2003c). Self-kindness adalah sikap baik hati, lembut, mempedulikan, perhatian, dan pengertian terhadap diri sendiri, daripada sikap terlalu menilai atau mengkritik secara tajam. Recognition of common humanity adalah kesadaran bahwa semua manusia mengalami kegagalan, membuat kesalahan, dan merasak tidak adekuat, dan merasa terhubung (connected) dengan manusia lain saat mengalami kesulitan. Mindfulness merupakan penerimaan terhadap apa yang sedang terjadi pada saat ini, penerimaan tanpa penilaian dan dilihat secara jelas; dalam kata lain, mindfulness adalah melihat keadaan seperti apa adanya.

Self-compassion berbeda dari self-esteem; untuk mendapat self-esteem tinggi, individu harus memandang dirinya sebagai lebih baik dari rata-rata dan seringkali bergantung pada perbandingan dengan orang lain untuk mendapat penilaian diri. Self-compassion, sebaliknya, merupakan sikap yang menerima dan tidak menilai diri sendiri, bebas dari perbandingan dengan orang lain, dan selfcompassion tinggi memberi perasaan diterima dan aman pada diri sendiri. Self-esteem yang tinggi tidak selalu didampingi self-compassion yang tinggi (Neff, 2011).

Self-compassion, sebagai suatu proses kognitif, dapat terlibat dalam cognitive appraisal yang dilakukan individu terhadap stressor. Berbagai penelitian telah menemukan bahwa terdapat hubungan negatif antara self-compassion dan stres (Sirois, Hirsch, \& Molnar, 2015; Brion, Leary, \& Drabkin, 2014; Bluth \& Blanton, 2014; Sirois, 2013). Individu yang memiliki self-compassion dapat melihat kegagalan (suatu stressor) sebagai kesempatan untuk belajar dan berkembang, dan tidak merasa takut terhadap kegagalan yang telah terjadi; maka, self-compassion memengaruhi persepsi individu terhadap suatu stressor dan dapat membantu individu menangani stres (Neff, Hsieh, \& Dejitterat, 2005). Penelitian lain juga menemukan bahwa self-compassion dapat meningkatkan kemampuan coping individu terhadap stres; individu yang memiliki selfcompassion cenderung tidak membesar-besarkan situasi negatif yang terjadi pada mereka dan tidak merasa cemas saat mengalami stres (Allen \& Leary, 2010).

Proses kognitif lain yang dapat berperan dalam cognitive appraisal adalah perceived social support. Memahami definisi perceived social support akan lebih mudah bila terlebih dahulu dipahami definisi dari social support. Social support adalah informasi dan feedback dari orang lain kepada individu yang mengindikasikan bahwa orang lain cinta, sayang, peduli, dan menghargai individu tersebut, dan bahwa individu tersebut merupakan bagian dari suatu jaringan sosial (King, 2011). Mattson dan Hall (2011) mendefinisikan social support sebagai proses komunikasi verbal 
atau nonverbal yang transaktif dan bertujuan untuk meningkatkan rasa kompetensi, coping, belonging, dan/atau harga diri individu. Individu yang memiliki social support akan merasa dicintai, dihargai, dan merupakan bagian dari jaringan sosial yang dapat memberikan bantuan saat diperlukan (Sarafino \& Smith, 2014). Cohen, Underwood, dan Gottlieb (2000) menambahkan bahwa social support termasuk proses apapun di mana hubungan sosial dapat meningkatkan kesejahteraan dan kesehatan seseorang.

Social support dapat dikategorikan menjadi actual atau enacted social support dan perceived social support (Mattson \& Hall, 2011; Lakey, n.d.). Actual atau enacted social support adalah dukungan yang diberikan kepada individu, sedangkan perceived social support adalah pandangan individu bahwa social support dimiliki atau telah diterima. Hlebec, Mrzel, dan Kogovšek (2009) menjelaskan perceived social support sebagai persepsi individu bahwa dukungan sosial ada saat dibutuhkan; individu percaya bahwa dukungan dari lingkungan sosial akan didapatkan saat diperlukan. Perceived social support memiliki dampak yang lebih signifikan terhadap penerima social support, karena perceived social support merujuk pada perasaan individu bahwa dukungan memang telah diberikan dan bahwa dukungan tersebut diperlukan atau sudah cukup (Mattson \& Hall, 2011).

Perceived social support merupakan persepsi bahwa dukungan sosial tersedia atau telah diberikan. Maka, perceived social support adalah komunikasi verbal atau nonverbal yang meningkatkan rasa kompetensi, coping, belonging, dan/atau harga diri individu; memberikan kepercayaan pada individu bahwa ia disayangi, dipedulikan, dan dapat membangun hubungan yang intim; bahwa ia diapresiasi dan dihormati; bahwa ia berbagi kewajiban, komunikasi, dan kebersamaan dengan orang lain; bahwa ia memiliki akses ke informasi, nasehat, dan panduan dari orang lain; dan bahwa ia memiliki akses ke bantuan materil atau fisik.

Perceived social support, sebagai suatu proses kognitif, dapat terlibat dalam cognitive appraisal yang dilakukan individu terhadap stressor. Beberapa penelitian telah menemukan terdapat hubungan signifikan dan negatif antara perceived social support dan stres (Çivitci, 2015; Lynch, 2012), perceived social support memiliki efek yang positif pada stres (Panayiotou \& Karekla, 2012), dan perceived social support dapat mengurangi stres (Kwan, 2014).

Self-compassion dan perceived social support memiliki kesamaan; kedua variabel tersebut merupakan sumber kasih sayang dan dukungan bagi individu. Hal yang membedakan kedua variabel tersebut adalah self-compassion merupakan sumber kasih sayang dan dukungan yang internal (datang dari dalam diri individu), sedangkan perceived social support merupakan sumber eksternal (datang dari luar diri individu). Selain itu, walaupun berbagai penelitian telah menemukan adanya hubungan antara tingkat stres dan self-compassion, dan adanya hubungan antara tingkat stres dan perceived social support, korelasi antara tingkat stres karena daily hassles dengan self-compassion dan korelasi antara tingkat stres karena daily hassles dengan perceived social support tidak pernah dibandingkan secara langsung dalam satu penelitian sebelumnya. Perbandingan antara self-compassion dan perceived social support dan kesadaran akan kurangnya penelitian dalam hal ini membuat peneliti tertarik untuk meneliti apakah sumber kasih sayang dan dukungan internal atau eksternal, sebagaimana direpresentasikan oleh self-compassion dan perceived social support, yang dapat menjadi prediktor lebih baik untuk stres yang disebabkan daily hassles. Penelitian dilakukan pada mahasiswa karena mahasiswa merupakan kelompok rentan mengalami stres yang disebabkan oleh daily hassles.

Berdasarkan pemaparan di atas, peneliti ingin membuktikan variabel mana yang lebih kuat memprediksi stres yang disebabkan daily hassles pada mahasiswa, apakah self-compassion yang 
berasal dari dalam diri mahasiswa atau perceived social support yang bersumber dari lingkungan di luar mahasiswa.

\section{METODE PENELITIAN \\ Partisipan}

Karakteristik partisipan dalam penelitian ini adalah mahasiswa yang sedang aktif berkuliah dan dalam satu bulan terakhir tidak mengalami kejadian atau perubahan relatif besar yang dapat merupakan penyebab stres; dalam kata lain, partisipan hanya mengalami stres karena daily hassles, dan bukan karena perubahan besar. Partisipan terdiri dari 573 mahasiswa. 212 orang (37\%) berjenis kelamin laki-laki, dan 361 orang (63\%) berjenis kelamin wanita. Rentang usia partisipan merupakan 17-26 tahun. Partisipan terdiri dari orang-orang yang menganut agama Islam, Katholik, Protestan, Hindhu, Budha, Kong $\mathrm{Hu} \mathrm{Cu}$, Kepercayaan terhadap Tuhan, atau agama lainlain. Partisipan terdiri dari mahasiswa dari enam perguruan tinggi di Jakarta, dan sedang menempuh semester pendidikan dua, empat, enam, delapan, dan sepuluh.

\section{Setting dan instrumen penelitian}

Pengumpulan data dilakukan di berbagai lokasi. Kuisioner disebarkan di berbagai perguruan tinggi dan tempat rekreasi di mana terdapat partisipan yang memenuhi kriteria penelitian. Pengumpulan data juga dilakukan melalui aplikasi GoogleDoc untuk menjangkau partisipan-partisipan lain yang tidak dapat ditemui secara langsung. Kuisioner yang dibagikan kepada partisipan terdiri dari lima bagian; surat pengantar (informed consent), data diri, dan alat-alat ukur stres yang disebabkan daily hassles, self-compassion, dan perceived social support.

\section{Alat-alat ukur}

Alat ukur yang digunakan untuk mengukur stres yang disebabkan daily hassles adalah Perceived Stress Scale dengan 10 butir (PSS-10) yang dirancang oleh Cohen, Kamarck, dan Mermelstein (1983) dan sudah diadaptasi. PSS-10 pertama diterjemahkan dari Bahasa Inggris ke Bahasa Indonesia. Kemudian ditambahkan suatu bagian di awal alat ukur yang meminta partisipan untuk hanya memikirkan tentang daily hassles saat menjawab butir-butir yang mengukur stres. Di akhir alat ukur, partisipan juga ditanyakan apakah mereka telah mengalami stressor yang berupa kejadian atau perubahan besar (stressor yang bukan daily hassles) selama satu bulan terakhir, dan bila iya, partisipan diminta untuk menulis dan menjelaskan kejadian atau perubahan besar apa yang telah terjadi kepada mereka. Hal ini dilakukan untuk memastikan bahwa tingkat stres yang diukur hanya disebabkan oleh daily hassles dan bukan disebabkan stressor jenis lain. PSS-10 terdiri dari 10 butir pernyataan, dan partisipan diminta untuk memberi nilai $0-4$ yang menandakan seberapa sering pernyataan tersebut berlaku bagi mereka dalam satu bulan terakhir, di mana 0 melambangkan "tidak pernah", 1 melambangkan "hampir tidak pernah", 2 melambangkan "kadang-kadang", 3 melambangkan "cukup sering", dan 4 melambangkan "sangat sering". PSS-10 terdiri dari enam butir positif dan empat butir negatif.

Alat ukur yang digunakan untuk mengukur tingkat self-compassion yang dimiliki partisipan adalah Self-compassion Scale (SCS) yang dirancang oleh Neff (2003c) dan telah diadaptasi dari bahasa Inggris menjadi bahasa Indonesia. SCS mengukur self-compassion individu, yaitu sikap memperlakukan diri sendiri dengan baik, pengertian, mendukung, dan penuh kasih sayang. Setiap butir SCS merupakan suatu pernyataan, dan partisipan diminta untuk memilih satu angka dari satu (1) sampai lima (5) yang mengindikasikan seberapa sering pernyataan tersebut berlaku untuk partisipan, di mana angka satu (1) melambangkan "hampir tidak pernah" dan angka lima (5) melambangkan "hampir selalu". Semakin tinggi skor variabel self-compassion, maka semakin tinggi tingkat self-compassion yang dimiliki partisipan. SCS memiliki total 26 butir dan terdiri dari enam dimensi, yaitu tiga dimensi positif dan tiga dimensi negatif. Dimensi positif terdiri dari 
self-kindness, recognition of common humanity, dan mindfulness. Dimensi negatif terdiri dari selfjudgment, isolation, dan over-identification.

Alat ukur yang digunakan untuk mengukur tingkat perceived social support yang dimiliki partisipan adalah Multidimensional Scale of Perceived social support (MSPSS) oleh Zimet, Dahlem, Zimet, \& Farley (1988) dan telah diterjemahkan dari bahasa Inggris ke bahasa Indonesia. Semua butir MSPSS berupa butir positif, dan merupakan suatu pernyataan; partisipan diminta untuk memilih satu pilihan jawaban yang mengindikasikan seberapa setuju partisipan dengan pernyataan tersebut. Pilihan jawaban dilambangkan dengan 1 untuk "sangat tidak setuju", 2 untuk "tidak setuju", 3 untuk "agak tidak setuju", 4 untuk "netral", 5 untuk "agak setuju", 6 untuk "setuju", dan 7 untuk "sangat setuju". MSPSS memiliki total 12 butir dan terdiri dari tiga dimensi, yaitu perceived social support dari orang yang spesial, perceived social support dari keluarga, dan perceived social support dari teman. Peneliti sudah melakukan metode analisa data regresi berganda dan persyaratan uji homogenitas telah terpenuhi.

\section{HASIL DAN PEMBAHASAN}

Hasil analisa menemukan bahwa stres karena daily hassles yang dialami partisipan secara umum dapat dikatakan rendah; hal ini disimpulkan dari hasil mean empirik $(1,89)$ yang lebih rendah dari mean hipotetik (2). Self-compassion partisipan secara umum dapat dikatakan tinggi; hal ini disimpulkan dari hasil mean empirik $(3,35)$ yang lebih tinggi dari mean hipotetik (3). Perceived social support partisipan secara umum dapat dikatakan tinggi; hal ini disimpulkan dari hasil mean empirik $(5,37)$ yang lebih tinggi dari mean hipotetik (4).

Untuk menganalisa self-compassion dan perceived social support sebagai prediktor stres yang disebabkan daily hassles, digunakan teknik analisa regresi ganda, di mana self-compassion dan perceived social support merupakan variabel independen pertama dan kedua, dan stres yang disebabkan daily hassles merupakan variabel dependen. Hasil analisa regresi ganda menunjukkan self-compassion dan perceived social support memprediksi stres yang disebabkan daily hassles sebesar $38.10 \%, \mathrm{~F}=175.639, \mathrm{p}<0.0005$. Hasil analisa juga menunjukkan self-compassion (nilai Beta $=-0.586, t=-16.931, p=.000<.05$ ) lebih dapat memprediksi stres yang disebabkan daily hassles dibandingkan dengan perceived social support (nilai Beta $=-0.086, t=-2.496, p=.013<$ .05). Berdasarkan hasil analisa regresi ganda tersebut, dapat disimpulkan bahwa self-compassion secara signifikan lebih mampu memprediksi stres yang disebabkan daily hassles dibandingkan dengan perceived social support.

Berdasarkan hasil uji regresi ganda terhadap keenam dimensi self-compassion sebagai variabelvariabel independen dan stres yang disebabkan daily hassles sebagai variabel dependen, didapatkan hasil adjusted $R^{2}=0.412$, yang artinya sumbangan keenam dimensi self-compassion terhadap stres yang disebabkan daily hassles adalah $41.2 \%, F=67.875$ dan $p=0.000<0.01$. Hasil uji regresi ganda juga menemukan bahwa dimensi isolation memiliki kemampuan untuk memprediksi stres karena daily hassles yang paling baik (nilai Beta $=-0.216, \mathrm{t}=-4.036, p<0.01$ ). Sedangkan dimensi over-identification menempati urutan kedua (nilai Beta $=-0.190, \mathrm{t}=-3.836, p$ $<0.01$ ). Dimensi self-kindness menempati posisi ketiga (nilai Beta $=-0.177, \mathrm{t}=-4.091, p<0.01$ ). Selanjutnya dimensi mindfulness menempati urutan keempat (nilai Beta $=-0.173, \mathrm{t}=-3.943, p<$ 0.01). Dimensi self-judgment menempati posisi kelima (nilai Beta $=-0.150, \mathrm{t}=-3.054, p<0.01$ ). Terakhir, dimensi recognition of common humanity menempati posisi ketiga (nilai Beta $=-0.119$, $\mathrm{t}=-2.894, p<0.01)$. 
Berdasarkan hasil uji regresi ganda terhadap ketiga dimensi perceived social support sebagai variabel-variabel independen dan stres yang disebabkan daily hassles sebagai variabel dependen, didapatkan hasil adjusted $R^{2}=0.073$, yang artinya sumbangan keenam dimensi perceived social support terhadap stres yang disebabkan daily hassles adalah $7.3 \%, \mathrm{~F}=16.111$ dan $\mathrm{p}=0.000<$ 0.01. Hasil uji juga menemukan dimensi friends dapat memprediksi stres yang disebabkan daily hassles dengan paling baik (nilai Beta $=-0.205, \mathrm{t}=-4.258, p<0.01$ ). Sedangkan dimensi family menempati urutan kedua (nilai Beta $=-0.080, \mathrm{t}=-1.814, p>0.05$ ). Terakhir, dimensi special person menempati posisi ketiga (nilai Beta $=-0.056, \mathrm{t}=-1.147, p>0.05$ ).

Hasil analisis data menunjukkan bahwa tingkat stres karena daily hassles yang dialami partisipan penelitian memiliki rentang dari rendah (skor minimum $=0.10$ ) hingga tinggi (skor maksimum $=$ 4.00), dan secara umum partisipan memiliki tingkat stres karena daily hassles yang dapat dikatakan rendah $(\mathrm{M}=1.89)$. Hal ini sesuai dengan berbagai hasil penelitian yang menemukan bahwa mahasiswa seringkali mengalami stres, baik dalam tingkat rendah, rata-rata, atau tinggi (Apremahirsty \& Paramita, 2013; Pathmanathan \& Husada, 2013; American College Health Association, 2013; Fitasari, 2011; Carolin, 2010; Associated Press \& mtvU, 2009, 2008; Abdulghani, 2008). Lazarus dan Folkman (1984) menyatakan bahwa stres yang dialami individu ditentukan oleh cognitive appraisal yang dilakukan individu terhadap stressor. Hal ini dapat menjelaskan variasi tingkat stres yang dialami partisipan. Walau para partisipan mengalami stressor yang sama (yaitu daily hassles yang dialami mahasiswa), tingkat stres yang dialami dapat berbeda-beda. Dua mahasiswa yang dihadapi tugas presentasi yang sama dapat merasakan tingkat stres yang berbeda, di mana satu mahasiswa dapat merasa gugup tapi tetap percaya diri, tetapi mahasiswa lainnya merasa sangat cemas dan takut. Hal ini menunjukkan keberadaan stressor tidak selalu menentukan tingkat stres yang akan dialami individu; yang menentukan tingkat stres yang dialami individu adalah penilaian individu terhadap suatu stressor. Penilaian tersebut merupakan penilaian yang pada akhirnya akan membuat individu percaya ia dapat menghadapi suatu stressor, atau percaya bahwa stressor tersebut terlalu berat untuk ditangani.

Berbagai penelitian sebelumnya juga telah menemukan mahasiswa merupakan kelompok yang rentan mengalami stres karena dalam kehidupan sehari-hari, mereka sering mengalami berbagai daily hassles. Berbagai daily hassles yang ditemukan dialami mahasiswa termasuk mendapat nilai buruk atau tidak sesuai harapan, kekhawatiran saat akan melakukan presentasi oral, persiapan untuk presentasi, kesulitan dalam menyusun skripsi, menghadapi mata kuliah yang dianggap sulit atau tidak penting, adanya praktik, deadline tugas, peraturan atau kebijakan-kebijakan kampus, jadwal perkuliahan, sikap para dosen atau dosen yang tidak disukai, materi kuliah yang membingungkan, tidak bisa mengatur waktu, bekerja, menjalankan program magang atau memiliki banyak kegiatan sehingga tumpang tindih dengan jadwal kuliah dan terjadi prokrastinasi, masalah dengan keluarga, masalah dengan teman, masalah dalam hubungan interpersonal lainnya (seperti pacar), kekhawatiran finansial, kekhawatiran tentang kesehatan fisik dan mental, kekhawatiran tentang mendapat pekerjaan setelah lulus kuliah, kekhawatiran tentang pendidikan selanjutnya, dan masalah perjalan sehari-hari seperti jarak yang jauh antara rumah dan kampus dan kondisi jalan yang macet. Banyaknya variasi daily hassles yang dapat dihadapi mahasiswa memberikan kesan bahwa mahasiswa tentu akan mengalami tingkat stres yang tinggi. Namun, berbagai penelitian sebelumnya dan juga penelitian ini menemukan bahwa stres yang dialami mahasiswa tidak selalu tinggi; stres yang dialami mahasiswa bervariasi, dari tingkat tinggi, tingkat sedang, sampai tingkat rendah. Hal ini lagi menunjukkan bahwa keberadaan stressor sendiri tidak menentukan tingkat stres yang akan dialami individu. Terdapat faktor-faktor lain yang mempengaruhi tingkat stres individu. Salah satu faktor tersebut adalah kepercayaan individu bahwa individu mampu mengatasi stressor yang sedang dialami. 
Penelitian ini menemukan bahwa self-compassion dapat memprediksi stres yang disebabkan daily hassles pada mahasiswa secara signifikan, di mana semakin tinggi self-compassion yang dimiliki partisipan, maka semakin rendah tingkat stres karena daily hassles yang dialami partisipan. Hasil temuan ini sejalan dengan berbagai hasil penelitian sebelumnya yang telah menemukan bahwa terdapat hubungan yang negatif dan signifikan antara self-compassion dan stres (Sirois, Hirsch, \& Molnar, 2015; Brion, Leary, \& Drabkin, 2014; Sirois, 2013). Kepercayaan individu bahwa suatu stressor dapat ditangani atau tidak ditentukan oleh penilaian yang dilakukan individu tentang kemampuannya untuk mengatasi stressor tersebut. Hubungan negatif dan signifikan antara tingkat stres dan self-compassion yang telah ditemukan berbagai penelitian terdahulu dan juga penelitian ini mengindikasikan bahwa penilaian yang dilakukan individu terhadap suatu stressor dapat dipengaruhi oleh self-compassion yang dimiliki individu.

Terdapat beberapa jawaban yang dapat menjelaskan mekanisme bagaimana self-compassion dapat mempengaruhi tingkat stres. Self-compassion termasuk self-kindness, yaitu sikap yang menyayangi, perhatian, dan baik hati terhadap diri sendiri saat mengalami kesulitan; maka, individu dengan self-compassion tinggi yang mengalami stressor akan mampu memberikan dukungan emosional terhadap diri sendiri, juga mampu menghibur dan menenangkan diri saat mengalami situasi yang menantang. Self-compassion juga termasuk recognition of common humanity; maka, individu yang memiliki self-compassion akan memiliki kesadaran bahwa stressor merupakan hal yang dialami hampir semua manusia dan bahwa mengalami masalah adalah hal yang manusiawi. Kesadaran bahwa individu tidak sendiri dalam kesulitannya dapat merendahkan tingkat stres yang dialami individu. Self-compassion juga termasuk kemampuan untuk melihat keadaan seperti apa adanya. Hal ini dapat mendorong individu untuk menilai stressor yang dialami secara objektif dan tanpa membesar-besarkannya. Individu dapat juga menyadari bahwa masalah yang sedang dialami secara relatif 'lebih ringan' daripada bencana besar yang sedang dialami orang lain; hal ini dapat membuat individu menilai situasi yang dialami sebagai tidak terlalu buruk, dan mengurangi tingkat stres yang dialami individu. Petunjuk lain mengenai mekanisme bagaimana self-compassion dapat mempengaruhi tingkat stres didapatkan dari hasil penelitian Allen dan Leary (2010), yang menemukan bahwa individu dengan tingkat self-compassion tinggi cenderung melakukan positive cognitive restructuring saat menghadapi stressor. Hasil penelitian ini memberikan petunjuk bahwa individu dengan tingkat self-compassion tinggi cenderung akan mengubah pandangan yang dimiliki terhadap stressor menjadi pandangan yang lebih positif, dan memiliki cara pandang yang membuat stressor tampak tidak begitu menakutkan.

Penelitian ini juga menemukan bahwa perceived social support dapat memprediksi stres yang disebabkan daily hassles pada mahasiswa secara signifikan, di mana semakin tinggi perceived social support yang dimiliki partisipan, maka semakin rendah tingkat stres karena daily hassles yang dialami partisipan. Hasil temuan ini sejalan dengan berbagai hasil penelitian yang telah menemukan bahwa terdapat hubungan yang negatif dan signifikan antara perceived social support dan stres (Kwan, 2014; Lynch, 2012; Panayiotou \& Karekla, 2012); maka, terdapat indikasi bahwa penilaian yang dilakukan individu terhadap stressor dapat dipengaruhi oleh perceived social support yang dimiliki individu.

Salah satu kemungkinan mekanisme pengaruh perceived social support pada tingkat stres adalah sebagai berikut; individu yang memiliki perceived social support percaya bahwa mereka memiliki dan bisa mendapatkan dukungan sosial yang mereka butuhkan. Saat mengalami stressor, individu yang memiliki perceived social support akan merasa bahwa ada orang-orang yang dapat membantu mereka. Hal ini dapat menyebabkan individu menilai stressor sebagai suatu hal yang tidak terlalu menantang, karena individu percaya bahwa bantuan dari orang lain yang diperlukan untuk menangani stressor akan didapatkan; maka, individu akan mengalami tingkat stres yang 
rendah. Individu yang memiliki perceived social support juga akan merasa disayangi dan dipedulikan oleh orang lain; hal ini dapat menjadi bentuk penyemangat bagi individu untuk mengatasi stressor, dan meningkatkan motivasi individu untuk menangani stressor, sehingga tingkat stres yang dialami akan berkurang.

Petunjuk lain mengenai mekanisme bagaimana perceived social support dapat mempengaruhi tingkat stres didapatkan dari hasil penelitian Faleel, Tam, Lee, Har, dan Foo (2012), yang menemukan bahwa terdapat hubungan positif yang signifikan antara perceived social support dan kemampuan coping, dan terdapat hubungan negatif yang signifikan antara kemampuan coping dan tingkat stres. Hasil penelitian ini mengindikasikan bahwa individu yang memiliki perceived social support dapat melakukan coping dengan lebih baik, dan karena itu akan mengalami tingkat stres yang lebih rendah.

Hasil analisis data juga menemukan bahwa self-compassion lebih dapat memprediksi stres yang disebabkan daily hassles pada mahasiswa, dibandingkan perceived social support. Hal ini menunjukkan bahwa hubungan antara self-compassion dan tingkat stres lebih kuat daripada hubungan antara perceived social support dan tingkat stres. Berdasarkan hal tersebut, dapat dikatakan bahwa dukungan dan kasih sayang yang datang dari diri sendiri lebih mempengaruhi tingkat stres karena daily hassles yang dialami partisipan, daripada dukungan dan kasih sayang dari orang lain. Individu yang merasa disayangi dan didukung orang lain belum tentu akan mengalami tingkat stres rendah, namun individu yang mampu menyayangi dan mendukung diri sendiri memiliki kemungkinan lebih besar untuk mengalami tingkat stres rendah. Hasil ini mengindikasikan bahwa individu sebenarnya lebih bergantung pada diri sendiri untuk mendapat dukungan dan kasih sayang daripada bergantung pada orang lain. Pendapat individu tentang dirinya sendiri dan situasi yang sedang dialami sebenarnya lebih dipengaruhi oleh pendapat yang dimiliki sang individu sendiri, daripada pendapat yang menurut individu dimiliki orang lain.

Penelitian ini memiliki beberapa keterbatasan. Pertama, semua partisipan merupakan mahasiswa dari perguruan tinggi swasta; maka apabila ingin dilakukan generalisasi, sebaiknya hanya dilakukan terhadap mahasiswa yang berkuliah di perguruan tinggi swasta. Kedua, beberapa data didapatkan melalui aplikasi GoogleDoc dalam kondisi di mana peneliti tidak dapat mengontrol dan memastikan keseriusan partisipan dalam mengisi kuesioner.

\section{KESIMPULAN DAN SARAN}

Peneliti menemukan bahwa baik kedua variabel yakni self-compassion dan perceived social support pada mahasiswa terbukti memprediksi stres karena daily hassles. Hasil penelitian menunjukkan beberapa hal. Pertama, variabel self-compassion lebih kuat memprediksi stres yang disebabkan daily hassles dibandingkan dengan variabel perceived social support pada mahasiswa. Kedua, dimensi self-compassion yang paling kuat memprediksi stres karena daily hassles adalah dimensi isolation. Ketiga, sumber perceived social support yang paling mampu memprediksi stres karena daily hassles adalah perceived social support yang didapatkan dari teman.

Hasil dari penelitian ini memberikan gambaran tingkat self-compassion, perceived social support, dan stres karena daily hassles yang dimiliki mahasiswa; maka, hasil penelitian ini dapat memberikan gambaran tentang kehidupan dan kondisi psikologis mahasiswa, dan dapat dijadikan basis untuk penelitian selanjutnya. Penelitian selanjutnya bahkan dapat melakukan replikasi dari penelitian ini, tetapi dengan menggunakan teknik sampling yang lebih baik dari penelitian ini dan mengambil sampel yang lebih representatif terhadap segala karakteristik mahasiswa di Indonesia; dengan itu, hasil dari penelitian selanjutnya benar-benar dapat digeneralisasikan kepada semua mahasiswa Indonesia. Untuk mendapat gambaran mengenai populasi yang lebih spesifik, penelitian selanjutnya dapat menerapkan kontrol terhadap berbagai kriteria populasi, seperti jenis 
perguruan tinggi, lokasi perguruan tinggi, jenis program studi atau fakultas, atau jenjang semester yang sedang ditempuh.

Self-compassion merupakan konsep psikologis yang relatif 'muda' dan belum banyak diteliti, termasuk di Indonesia. Hasil penelitian menemukan bahwa self-compassion dapat memprediksi tingkat stres lebih baik daripada perceived social support; hal ini menunjukkan bahwa selfcompassion merupakan konsep psikologis yang cukup penting, dan layak untuk diteliti lebih lanjut. Self-compassion dapat diteliti pada karakteristik partisipan yang lain, atau diuji dengan variabel psikologi lainnya. Penelitian selanjutnya juga dapat mencoba mencari tahu faktor-faktor apa saja yang memengaruhi self-compassion individu, khususnya individu di Indonesia, untuk mendapat pengetahuan tentang apa yang dapat dilakukan untuk membantu meningkatkan selfcompassion orang Indonesia.

Saran yang dapat diberikan untuk penelitian selanjutnya adalah meneliti stres yang disebabkan segala jenis stressor dan hubungannya dengan self-compassion dan perceived social support, baik pada karakteristik partisipan yang sama maupun yang berbeda. Penelitian ini hanya mengukur stres yang disebabkan daily hassles, sehingga penyebab-penyebab lain dapat memberikan gambaran yang lebih kaya mengenai prediktor stres.

\section{Ucapan Terima Kasih (Acknowledgement)}

Peneliti mengucapkan terima kasih kepada partisipan yang telah meluangkan waktunya untuk mengikuti penelitian ini. Peneliti juga mengucapkan terima kasih kepada pihak universitas yang telah mendukung penelitian ini.

\section{REFERENSI}

Abdulghani, H. M. (2008). Stress and depression among medical students: A cross sectional study at a medical college in Saudi Arabia. Pak J Med Sci, 24(1), 12-17.

Ainscough, L., Stewart, E., Colthorpe, K., \& Zimbardi, K. (2017). Learning hindrances and selfregulated learning strategies reported by undergraduate students: identifying characteristics of resilient students. Studies in Higher Education, 1-16. doi:10.1080/03075079.2017.1315085

Allen, B. A., \& Leary, M. R. (2010). Self-compassion, stress, and coping. Social and Personality Psychology Compass, 4(2), 107-118.

American College Health Association. (2013). American College Health Association-National College Health Assessment II: Reference Group Undergraduates Executive Summary Spring 2013. Hanover, MD: American College Health Association.

Apremahirsty, K. C., \& Paramita, G. V. (2013). Hubungan antara academic locus of control dengan tingkat stres pada mahasiswa Universitas Bina Nusantara (Unpublished master's thesis). Universitas Bina Nusantara.

Associated Press \& mtvU. (2008). Economy, college stress and mental health poll [Press release]. Diambil dari http://www.halfofus.com/wp-content/uploads/2013/10/mtvU-AP-2009Economy-College-Stress-and-Mental-Health-Poll-Executive-Summary-May-2009.pdf

Associated Press \& mtvU. (2008). Economy, college stress and mental health poll [Press release]. Diambil dari http://www.halfofus.com/wp-content/uploads/ 2013/10/mtvU-AP-CollegeStress-and-Mental-Health-Poll-Full-Version.pdf

Bluth, K., \& Blanton, P. W. (2014). The influence of self-compassion on emotional well-being among early and older adolescent males and females. The Journal of Positive Psychology, 10(3), 219-230. doi:10.1080/17439760.2014.936967 
Brion, J. M., Leary, M. R., \& Drabkin, A. S. (2014). Self-compassion and reactions to serious illness: The case of HIV. Journal of Health Psychology, 19(2), 218-229.

Buch, B. (2006). Salutogenesis and Shamanism (Unpublished masters thesis). University of Flensburg.

Carolin. (2010). Gambaran tingkat stres pada mahasiswa pendidikan sarjana kedokteran Universitas Sumatera Utara (Unpublished master's thesis). Universitas Sumatera Utara.

Çivitci, A. (2015). The Moderating Role of Positive and Negative Affect on the Relationship between Perceived Social Support and Stress in College Students. Educational Sciences: Theory \& Practice, 15(3). doi:10.12738/estp.2015.3.2553

Cohen, S., Kamarck, T., \& Mermelstein, R. (1983). A global measure of perceived stress. Journal of Health and Social Behavior, 24, 385-396.

Cohen, S., Underwood, L. G., \& Gottlieb, B. H. (2000). Social relationships and health. Dalam S. Cohen, L. G. Underwood, \& B. H. Gottlieb (Eds.). Social support measurement and intervention: A guide for health and social scientists. (pp. 3-25). New York: Oxford University Press.

Denovan, A., \& Macaskill, A. (2016). Stress and Subjective Well-Being Among First Year UK Undergraduate Students. Journal of Happiness Studies, 18(2), 505-525. doi:10.1007/s10902-016-9736-y

Faleel, S., Tam, C., Lee, T., Har, W., \& Foo, Y. (2012). Stress, perceived social support, coping capability and depression: A study of local and foreign students in the Malaysian context. International Journal of Social, Education, Economics and Management Engineering, 6(1), $1-7$.

Fitasari, I. N. (2011). Faktor yang berhubungan dengan kejadian stres pada mahasiswa fakultas kesehatan masyarakat Universitas Airlangga (Unpublished master's thesis). Universitas Airlangga.

Hlebec, V., Mrzel, M., \& Kogovsek, T. (2009). Social support network and received support at stressful events. Metodoloski zvezki, 6(2), 155-171.

Kanner, A. D., Coyne, J. C., Schaefer, C., \& Lazarus, R. S. (1981). Comparison of two modes of stress measurement: Daily hassles and uplifts versus major life events. Journal of Behavioral Medicine 4(1), 1-39. Hill.

King, L. A. (2011). The science of psychology: An appreciative view. New York: McGraw-

Kwan, M. Y. (2014). Does social support influence bulimic behaviors through its impact on cognitive appraisal? (Unpublished dissertation). North Dakota State University.

Lakey, B. (n.d.). Social Support and Social Integration. Diambil dari http://cancercontrol.cancer.gov/brp/constructs/social_support/social_support.pdf

Lazarus, R. S., \& Folkman, S. (1984). Stress, appraisal, and coping. New York: Springer Publishing Company.

Leppink, E. W., Odlaug, B. L., Lust, K., Christenson, G., \& Grant, J. E. (2016). The Young and the Stressed: Stress, Impulse Control, and Health in College Students. The Journal of Nervous and Mental Disease, 204(12), 931-938. doi:10.1097/nmd.0000000000000586

Lynch, J. G. (2012). Perceived stress and the buffering effect of perceived social support on facebook (Doctoral dissertation). Available from http://gradworks.umi.com/35/31/3531117.html

Mattson, M., \& Hall, J. G. (2011). Health as communication nexus: A service-learning approach. Dubuque, IA: Kendall Hunt Publishing Company.

Melisa \& Astrini (2012). Hubungan antara tingkat stres dengan perilaku prokrastinasi akademik pada mahasiswa Universitas Bina Nusantara yang sedang mengerjakan skripsi pada semester genap 2011/2012. (Unpublished dissertation). Universitas Bina Nusantara. 
Neff, K. D. (2003a). Self-compassion: An alternative conceptualization of a healthy attitude toward oneself. Self and Identity, 2, 85-101.

Neff, K. (2003b). Self-compassion: Stop beating yourself up and leave insecurity behind. New York: Harper Collins.

Neff, K. (2003c). The development and validation of a scale to measure self-compassion. Self and Identity, 2, 223-250.

Neff, K. D. (2011). Self-compassion, self-esteem, and well-being. Social and Personality Compass, 5, 1-12.

Neff, K. D., Hsieh, Y. P., \& Dejitterat, K. (2005). Self-compassion, achievement goals, and coping with academic faillure. Self and Identity, 4, 263-287.

Panayiotou, G., \& Karekla, M. (2012). Perceived social support helps, but does not buffer the negative impact of anxiety disorder on quality of life and perceived stress. Social Psychiatry. Published online. DOI 10.1007/s00127-012-0533-6.

Pathmanathan, V., \& Husada, M. S. (2013). Gambaran Tingkat Stres Pada Mahasiswa Fakultas Kedokteran Universitas Sumatera Utara Semester Ganjil Tahun Akedemik 2012/2013. E-Journal Fakultas Kedokteran Universitas Sumatera Utara, 1(1).

Purwati, S. (2012). Tingkat stres akademik pada mahasiswa reguler angkatan 2010 Fakultas Ilmu Keperawatan Universitas Indonesia (Unpublished master's thesis). Universitas Indonesia.

Sarafino, E. P., \& Smith, T. W. (2014). Health psychology: Biopsychosocial interactions $\left(8^{\text {th }}\right.$ ed.). New York: John Wiley \& Sons.

Sirois, F. M. (2013). Procrastination and stress: Exploring the role of self-compassion. Self and Identity, 13(2), 128-145.

Sirois, F. M. , Hirsch, J. K., \& Molnar, D. S. (2015). Self-compassion, stress, and coping in the context of chronic illness [Powerpoint slides]. Diambil dari http://positivepsychologycanada.com/Resources/Documents/Self-compassion \%20_\%20Coping\%20-\%20Fuschia\%20M.\%20Sirois.pdf

Zimet, G. D., Dahlem, N. W., Zimet, S. G., \& Farley, G. K. (1988). The multidimensional scale of perceived social support. Journal of Personality Assessment, 52(1), 30-41. 